\title{
Application of the direct sire comparison method to the Finnish dairy cattle population
}

\author{
JOUKO SYVÄJÄRVI', MATTI OJALA ${ }^{2}$ and TAPANI HELLMAN ${ }^{3}$ \\ ${ }^{1}$ The Finnish Animal Breeding Association, Cattle Breeding Department, \\ P.O. Box 40, 01301 Vantaa 30 \\ ${ }^{2}$ University of Helsinki, Department of Animal Breeding, 00710 Helsinki 71 \\ ${ }^{3}$ Central Association of A.I. Societies, Agricultural Data Processing Centre, \\ P.O. Box 25, 01301 Vantaa 30
}

\begin{abstract}
Data, consisting of a total of 400542 first lactation records completed in 1975 through 1982, were utilised for development of a model for ranking sires. Using the principle of direct sire comparison method (BLUP), sire evaluations were calculated assuming three models. Model 1 included random terms for sires and maternal grandsires (MGS) of cows, fixed sire and MGS groups within the three breeds and fixed two-year classes within herds. A two-year period within a herd was used to increase the number of records in a class. In model 2 genetic groups were only for breeds. Model 3 included fixed breed groups and herd-year classes. Relationships among bulls were used in all models.

About 83,13 and $2 \%$ of cows making the records were of the Finnish Ayrshire (FAy), the Finnish Friesian $(\mathrm{FFr})$ and the Finncattle $(\mathrm{Fc})$, respectively, while about $2 \%$ were of various crossbreds. About 20 $\%$ of the herd-year classes had cows of more than one breed. Practically all of the male ancestors of bulls and about 70 to $85 \%$ of maternal grandsires of cows were identified in recent years. About $7 \%$ of the total variation for fat corrected 305-day milk (FCM) production was accounted for by years within herds. The fraction of records lost in editing was $4 \%$ for models 1 and 2 , and $11 \%$ for model 3 . Assuming model 3 , the average numbers of daughters for bulls of the FAy-, FFr- and Fc-breeds were 130, 152 and 44, respectively. Average number of records in a herd-year class was about 3.6 in recent years. The additive genetic superiority of the FAy-breed in FCM-production to the FFr- and Fc-breeds was 84 and $860 \mathrm{~kg}$, respectively.

Joint use of bull groups and relationships among males (model 1) tended to underevaluate the youngest bulls and overevaluate the oldest bulls belonging to previous generations. Based on the results and the breeding structure in the Finnish dairy cattle population, model 3 was chosen to be used in official sire evaluation.
\end{abstract}

\section{Introduction}

A variant of the herdmate comparison method replaced the daughter-dam comparison in dairy sire evaluation in Finland in 1950. The change in evaluation method was, in part, a result from the studies by Dr. Varo (e.g., VARO 1952). The herdmate method was used with some modifications (e.g., 
VARO 1958, LINDSTRÖM et al. 1973) for about 30 years. Beginning in the spring of 1981, dairy sires have been evaluated using the direct sire comparison method which by statistical definition produces the best linear unbiased prediction (BLUP) of a sire's breeding value (HENDERSON 1973).

The mixed model used is the maternal grandsire model, similar to that in the Northeast United States (EVERETT et al. 1979). As generally known, the operational model is largely dictated by the structure of the population. Thus, it is questioned whether groups for sires and grandsires are necessary in the model under the Finnish data structure. Due to the small herd size, a fixed two-year period within a herd (H2Y-effect) is used in the model to account for differences between herds and years. After a poor fodder crop in the year of 1981, however, it was questioned whether the H2Y-effect should be replaced with the herd-year effect. This assumes that year effects share an important portion of the total variation for milk production records. On the other hand, replacing the $\mathrm{H} 2 \mathrm{Y}$-class by the HY-class, variance of error of prediction for sire proofs may increase because of loss of more records, and because the number of records for a young bull to be proved as well as in a herd-year subclass would decrease.

The objective of this paper is to present the structure of data and results from the comparison of three alternative models, and to propose a model suitable for ranking sires in the Finnish dairy cattle population.

\section{Structure of dairy cattle population and breeding in Finland}

In 1982 the Finnish dairy cattle population consisted of some 680000 cows, of which $43 \%$ were milk recorded (BOA 1983). In practice all recorded cows have for the past 10 years been bred by artificial insemination (AI). Of the milk recorded cows $81 \%$ was Finnish Ayrshire (FAy), $16 \%$ Finnish Friesian (FFr) and $2 \%$ Finncattle (Fc). The average number of cows in a herd was 12.2, and has steadily increased from 1975 through 1982 by 0.4 cows a year (BOA 1976-1983). In 1982 the majority, $77 \%$, of recorded cows was in herds with 10 or more cows.

Positive assortative mating for milk yield is probable since according to recommendations cows within a herd should be bred as follows: 1) 15 to $20 \%$ of best cows should be bred by selected bulls, 2) 15 to 20 $\%$ of the poorest cows should be bred by bulls of a beef breed, and 3) the rest of the herd, 60 to $70 \%$, consisting of mediocre cows and all heifers, should be bred randomly by young bulls. The breeding advisors of the Finnish Animal Breeding Association (FABA) have made specific mating plans in about 25 $\%$ of the recorded herds. The fractions of recorded cows bred by selected and beef bulls have recently averaged about 35 and $6 \%$, respectively (CAAIS 1983).

To avoid an increase of inbreeding and to simplify the work of the AI-technicians, bulls and cows are assigned to 3 breeding groups within each breed. The breeding group is determined according to a sire's group. General recommendation for AI-technicians is that a cow belonging to a group should be bred by a bull from another group. The prospective AI-bulls, however, are generally from planned matings in which both the cow and bull belong to the same breeding group. It has also been the policy to occasionally introduce imported semen to the FAy- and FFr-breeds from superior bulls of corresponding breeds. The imported semen is restricted to high quality cows, mainly to bull dams.

About $\mathbf{2 0 0}$ to $\mathbf{2 5 0}$ young bulls are annually proved for dairy characteristics. All of these bulls have passed the performance test in which culling, about $20 \%$, is mainly on growth rate. First inseminations, about 1500 to 2000 per young bull, are generally completed in about 6 months. Young bulls are usually used to cows within a certain geographical area, within an AI-stud. Due to collaboration between AIstuds, there are essentially 4 areas in the country in terms of progeny testing youngs bulls. After having collected about 20000 to 40000 doses of semen, the bulls are slaughtered at the age of about 3 to 4 years. 
Once the young bulls are proved, about $10 \%$ of them are selected. The semen storage of selected bulls is used in about 2 years to cows across the whole country.

The described structure of breeding leads to a distinct pattern in the age distribution for sires represented with first lactation daughters during one year. Bulls obtaining their first proof in a year $t$, were born on the average 6 years earlier, in a year of $t-6$. Selected bulls may obtain their second batch of first lactation daughters after about 5 years, i.e., they were born on the average in a year of $t-11$. Referring to the amount of semen available for and usage of selected bulls, it is obvious that the critical and most important part of sire evaluation is selection and correct ranking among the youngest classes of bulls.

The structure of the breeding program in Finland is similar to those in Sweden (DANELL and ERIKSSON 1982) and in Norway (FIMLAND 1976). The breeding program differs, however, from that in North America where the fraction of young bulls progeny tested is smaller and the number of lifetime first inseminations by selected bulls is larger than in North Europe (e.g., CUNNINGHAM 1983).

\section{Materials and methods}

The basic data set for the sire evaluation in the spring of 1983 consisted of a total of 400542 first lactation 305-day milk records. About 83, 13 and 2 percents of the cows making the records were of FAy-, FFr- and Fc-breeds, respectively, while about 2 percent were of various crossbreds (Table 1). Lactations were completed in 1975 through 1982. Data included about 24000 herds and 7000 bulls of which about 2200 bulls had 20 or more progeny.

Four traits, $4-\%$ fat corrected milk (FCM), protein, fat and milk yields in kilograms were included in sire evaluation. All traits were preadjusted for age-season of calving subclass effect with multiplicative correction (MC) factors which are estimated in every sire run. Age of calving consisted of 16 one-month classes, 21 months and younger through 36 months and older. Season of calving consisted of 6 two-month periods starting from January. Records were also adjusted for days open with MC-factors. The days open effect was coded to 20 ten-day periods, from 20 to 210 or more days after calving.

Table 1. Percent of first lactation cows of the FAy-, FFr- or Fc-breed, or of any combination of crossbreds in different years.

Breed of $\operatorname{cow}^{1)}$

Percent of cows of different breeds by the year the lactation was

\begin{tabular}{lrrrrrr} 
& \multicolumn{7}{c}{ initiated } & 1977 & 1978 & 1979 & 1980 & 1981 & $1982^{2)}$ \\
\hline The Finnish Ayrshire (FAy) & 84.7 & 83.8 & 83.8 & 84.2 & 83.3 & 83.1 \\
The Finnish Friesian (FFr) & 9.2 & 10.4 & 11.4 & 12.0 & 12.8 & 13.3 \\
The Finncattle (Fc) & 2.6 & 2.3 & 2.0 & 1.6 & 1.6 & 1.3 \\
The combination of a cross: & & & & & & \\
FAy x FFr or Fc & 0.3 & 0.4 & 0.4 & 0.4 & 0.5 & 0.5 \\
FFr x FAy or Fc & 3.1 & 3.0 & 2.3 & 1.7 & 1.7 & 1.7 \\
Fc x FAy or FFr & 0.1 & 0.1 & 0.1 & 0.1 & 0.1 & 0.1 \\
Total no. of records) & 37994 & 46547 & 45827 & 40849 & 50956 & 33614 \\
\hline
\end{tabular}

1) Determined by a combination of the breed of the sire and the breed of the maternal grandsire.

2) Year 1982 is incomplete.

3) Records of cows with identified sire and maternal grandsire. 


\section{Alternative models for sire evaluation}

Three models, which differed in grouping of sires and/or in classes accounting for herd and year effects, were compared. In describing the models, a detailed equation will be presented only for model 3 to which a reference will be made in the context of models 1 and 2. Due to editing, the size of data used in the final run was smaller for model 3 than for models 1 and 2 (Table 2).

In model 1, which was used in the officially approved sire evaluation until the fall of 1983 , sires were assigned within each breed to 5 groups according to their year of birth. The first two groups consisted of selected bulls whereas the last two groups comprised young bulls having their first batch of daughters only. The middle group may include bulls from both of the two classes. This pattern arises from the breeding structure of young and selected bulls as described previously. The equation included a fixed term consisting of a period of two consecutive years within a herd, the H2Y-effect. A two-year period was used to increase the number of records in a H2Yclass.

Equation for model 2 was the same as for model 1 except that no grouping of bulls within a breed was used. Based on several papers (e.g., HENDERSON 1973, KENNEDY and MOXLEY 1975, THOMPSON 1979, JENSEN 1980, KENNEDY 1981, QUAAS and POLLAK 1981, DEMPFLE 1982, FAMULA and VAN VLECK 1982, FAMULA et al. 1983, POLLAK and QUAAS 1983, SWALVE and BRUNS 1983) it seems that joint use of bull groups and relationships among males is difficult to justify under the Finnish breeding structure. Sires, and paternal and maternal grandsires of the young bulls were perfectly known in

Table 2. Size and structure of the data for the three models used in sire evaluation in the spring of 1983.

\begin{tabular}{lrr}
\hline Item & Models 1 and $2^{1)}$ & Model 3 \\
\hline Records accepted. no. & 384859 & 355706 \\
Records lost, \% ${ }^{2}$ & 3.9 & 11.2 \\
Ave. no. of records in one HY-class & 5.1 & 3.5 \\
Ave. no. of young bulls proved in one year-class: ${ }^{3)}$ & & 174.4 \\
The Finnish Ayrshire (FAy) & 176.0 & 30.6 \\
The Finnish Friesian (FFr) & 31.0 & 9.6 \\
The Finncattle (Fc) & 11.0 & 129.7 \\
Ave no. of daughters for the young bulls: & 141.8 & 152.3 \\
The FAy-breed & 168.7 & 43.9 \\
The FFr-breed & 48.3 & 4.9 \\
The Fc-breed & & \\
\hline
\end{tabular}

1) Model 1 includes $\mathrm{H} 2 \mathrm{Y}$-effect and sire groups within breeds, model 2 includes $\mathrm{H} 2 \mathrm{Y}$-effect and breed groups, and model 3 includes HY-effect and breed groups (see text for details).

2) Lost due to no contemporary record in the H2Y- or HY-class (see text for details).

3) From a sub-set of data consisting of young bulls having first batch of daughters only and having at least 20 progeny. 
the Finnish data. Due to the breeding structure, bulls for later use are selected from the youngest two or three classes of young bulls, all of which are the progeny of highly selected bull sires and dams. Thus, it seems that use of bull groups jointly with relationships among bulls, would improve only slightly, if at all, the accuracy of prediction of a sire's genetic merit.

Groups for the three breeds remained in the model, however, because all records are included in the same run irrespective of the breed. This is dictated by the relatively small number of records for the FFr- and Fc-breeds in general, and also because about $20 \%$ of the herd-year classes had cows of more than one breed (Table 3). Connectedness of the data between breeds comes mainly through mixed herds because the fraction of crossbred cows was relatively low (Table 1). Connections among young bulls within a breed in one geographical area are provided through the use of relationships among male ancestors of the bulls. This is further strengthened because about 70 to $85 \%$ of a cow's maternal grandsires were identified in the recent years (Table 4). In addition, the use of selected bulls across the whole country also adds to the connectedness of the data.

Table 3. Percent of herd-year classes having first lactation cows of one, two or three combinations of breeds in different years.

\begin{tabular}{lrrrrrr}
$\begin{array}{l}\text { A combination of } \\
\text { breeds for sires of } \\
\text { cows in one herd }\end{array}$ & \multicolumn{5}{c}{$\begin{array}{c}\text { Percent of herds with a certain combination } \\
\text { of breeds by the year the lactation was } \\
\text { initiated }\end{array}$} \\
& 1977 & 1978 & 1979 & 1980 & 1981 & $1982^{1)}$ \\
\hline The Finnish Ayrshire (FAy) & 73.0 & 72.5 & 72.0 & 69.9 & 69.2 & 73.1 \\
The Finnish Friesian (FFr) & 7.6 & 8.1 & 8.4 & 8.6 & 8.5 & 11.2 \\
The Finncattle (Fc) & 2.6 & 2.1 & 1.8 & 1.5 & 1.3 & 1.3 \\
FAy and FFr & 13.6 & 14.7 & 15.4 & 17.8 & 18.8 & 13.2 \\
FAy and Fc & 1.5 & 1.1 & 1.0 & 0.9 & 1.0 & 0.6 \\
FFr and Fc & 1.1 & 1.0 & 0.9 & 0.9 & 0.7 & 0.4 \\
FAy, FFr and Fc & 0.6 & 0.5 & 0.5 & 0.4 & 0.5 & 0.2 \\
Total no. of herds & 20083 & 20225 & 20041 & 20764 & 21084 & 18243 \\
\hline
\end{tabular}

1) Year 1982 is incomplete.

Table 4. Percent of identified maternal grandsires (MGS) of cows for different breeds in different years.

\begin{tabular}{lrrrrrrr}
\hline $\begin{array}{l}\text { Breed of the sire } \\
\text { of a cow }\end{array}$ & \multicolumn{7}{c}{$\begin{array}{c}\text { Percent of identified MGS of cows by the } \\
\text { year the lactation was initiated }\end{array}$} \\
& 1977 & 1978 & 1979 & 1980 & 1981 & $1982^{1)}$ \\
\hline The Finnish Ayrshire (FAy) & 72 & 86 & 84 & 68 & 81 & 85 \\
The Finnish Friesian (FFr) & 64 & 79 & 76 & 58 & 71 & 76 \\
The Finncattle (Fc) & 63 & 80 & 79 & 58 & 76 & 79 \\
Total no. of records & 53655 & 54849 & 55303 & 61478 & 64234 & 40242 \\
\hline
\end{tabular}

1) Year 1982 is incomplete. 
Model 3 was modified from model 2 by changing the H2Y-class to the herd-year class. The equation for model 3 is:

$$
y_{i j k l m n}=h_{i}+g_{i}+s_{i k}+0.5 g_{l}+0.5 s_{l m}+e_{i j k l m n}
$$

where

$\mathrm{y}_{\mathrm{ijk} \mid \mathrm{mn}}$ is a 305-day first lactation record adjusted for age-season of calving and days open effects,

$\mathrm{h}_{\mathrm{i}} \quad$ is a fixed effect of the ith herd-year,

$\mathrm{g}_{\mathrm{i}} \quad$ is a fixed effect of the jth breed of sires,

$s_{\mathrm{jk}} \quad$ is a random effect representing one-half the additive genetic merit of the kth sire within the jth breed,

$\mathrm{g}_{\mid} \quad$ is a fixed effect of the lth breed of maternal grandsires (MGS) of the cows making records,

$s_{\operatorname{lm}} \quad$ is a random effect representing one-half the additive genetic merit of the mth MGS within the lth breed, and

$\mathrm{e}_{\mathrm{ijk} k \mathrm{mn}}$ is a random residual associated with the record of the nth cow.

The one-year period for the HY-effect included 305-day lactation records initiated in the interval of May 1st through April 30 th. This period was chosen because then a maximum number of cows produce the major part of the 305-day lactation by the fodder crop harvested in one year. All relationships among bulls were utilized as described by HENDERSON (1975) and EVERETT et al. (1979).

\section{Relative variation of year effects within herds}

First lactation 305-day milk production records initiated in 1978 through 1981 by cows of FAy-breed were used to estimate the magnitude of relative variation for years within herds. Data included a total of 195478 records which were preadjusted with MC-factors for age-season of calving subclass effect and for days open effect. A simple random model including herds and years within herds was assumed. Thus, the residual component of variation includes both genetic and non-genetic effects. The model assumed and structure of data are implicit from Table 5.

Table 5. The relative magnitude of total variation accounted for by herds and years within herds.

\begin{tabular}{lrrrrr}
\hline $\begin{array}{l}\text { Source of } \\
\text { variation }\end{array}$ & $\begin{array}{c}\text { Degrees } \\
\text { of } \\
\text { freedom }\end{array}$ & $\begin{array}{c}\text { FCM } \\
\text { prod. }\end{array}$ & $\begin{array}{c}\text { Components of variance for } \\
\text { protein } \\
\text { prod. }\end{array}$ & $\begin{array}{c}\text { fat } \\
\text { prod. }\end{array}$ & $\begin{array}{c}\text { milk } \\
\text { prod. }\end{array}$ \\
\hline Total $^{1)}$ & 195477 & $806246 \mathrm{~kg}^{2}$ & $836 \mathrm{~kg}^{2}$ & $1506 \mathrm{~kg}^{2}$ & $755486 \mathrm{~kg}^{2}$ \\
Between herds & 23999 & $37.4 \%$ & $42.4 \%$ & $35.6 \%$ & $36.3 \%$ \\
Betw. years/herds & 49124 & $6.8 \%$ & $8.9 \%$ & $6.8 \%$ & $6.3 \%$ \\
Residual & 122354 & $55.8 \%$ & $48.7 \%$ & $57.6 \%$ & $57.4 \%$ \\
\hline
\end{tabular}

1) Data include 305-day first lactation records initiated by FAy-cows in 1978 through 1981, records are preadjusted for age-season of calving effect and for days open effect by multiplicative correction factors. 
Relative variation of year effects within herds

The importance of years in affecting a cow's milk production was evaluated by the percent of total variation accounted for by years within herds which was about $7 \%$ for traits of FCM, milk and fat production, and was about $9 \%$ for protein production (Table 5 ). Variance due to herd effects accounted for a large portion, about $36 \%$ of the total variation, for traits other than protein production.

The fraction of total variation accounted for by herd effects in this study is in general agreement with the value of $1 / 3$ summarized by CHRISTENSEN (1980) based on several studies. The magnitude of variance due to year effects within herds in this study suggests that this effect should be included in the model jointly with herd, as a herd-year subclass effect. Use of fixed HYclasses in the model in place of $\mathrm{H} 2 \mathrm{Y}$-effects can be expected to improve the efficiency in removing the bias caused by year effects on sire proofs.

\section{Consequences of replacing $\mathrm{H} 2 \mathrm{Y}$-effect by $\mathrm{HY}$-effect in the model}

Total number of records lost. In editing the data for a sire run, a record with no contemporary record in a herd-year class is lost. The same is true if all records in one HY-class are made by paternal half-sisters. Referring to Table 2 , about $4 \%$ of records were lost when a two-year period within a herd was used (models 1 and 2), in comparison to $11 \%$ of records lost when using HY-effect (model 3). The number of records lost reduced with time, about $11 \%$ in 1977 and $7 \%$ in 1981 (Table 6). The percent of records lost in this study is equal to or less than the percentages of records lost for the models assumed in Sweden (DANELL and ERIKSSON 1982) and in the Northern United States (JENSEN 1980).

Number of records lost in a progeny group. When H2Y-effect was replaced by HY-effect in the model, the reduction in the average number of daughters was about $9 \%$ for young bulls having at least 20 progeny (Table 2 ). Due to the relatively large number of progeny, the number of daughters lost is negligible relative to the accuracy of sire proofs for milk production traits. The number of daughters for young bulls of FAy- and FFr-breeds is about three to four times, and for Fc-breed about equal to that deemed sufficient (HEIDHUES et al. 1961) and obtained (EVERETT et al. 1979) in the Northeast United States. Relatively large number of progeny for bulls is favored in Finland because bulls are evaluated also for low-heritability traits such as fertility (see Appendix).

Size of $H Y$-subclass relative to the accuracy of sire proofs. In direct sire comparison, a progeny record is deviated from the average of all contemporary records in one herd-year subclass. Intuitively, it is expected that the estimated average of a HY-subclass, and consequently a deviation from the average, is more accurate with many contemporary records than with only a 
Table 6. Distribution of records in different size of herd-year (HY) subclasses in different years.

\begin{tabular}{lrrrrrr}
\hline $\begin{array}{l}\text { Size of } \\
\text { herd-year } \\
\text { subclass }\end{array}$ & \multicolumn{3}{c}{ Percent of records in different size of $\mathrm{HY}$ in the years of } \\
\hline $1^{2)}$ & 1977 & 1978 & 1979 & 1980 & 1981 & $1982^{1)}$ \\
2 & 11.0 & 10.6 & 10.1 & 8.1 & 7.4 & 17.4 \\
3 & 20.9 & 20.3 & 19.6 & 17.6 & 16.5 & 27.5 \\
4 & 21.1 & 21.1 & 21.2 & 20.7 & 20.1 & 22.4 \\
5 & 16.5 & 16.3 & 16.9 & 17.3 & 17.5 & 14.5 \\
6 & 11.0 & 11.6 & 11.3 & 12.5 & 13.6 & 8.3 \\
7 & 7.4 & 7.5 & 7.3 & 8.2 & 8.6 & 4.5 \\
8 & 4.1 & 4.6 & 4.7 & 5.8 & 6.3 & 2.3 \\
9 & 2.3 & 2.7 & 3.3 & 3.6 & 3.5 & 1.4 \\
10 & 1.5 & 1.4 & 1.5 & 1.7 & 2.1 & 0.4 \\
11 to 15 & 1.1 & 1.0 & 1.2 & 1.1 & 1.3 & 0.4 \\
$>15$ & 1.9 & 1.8 & 2.0 & 2.3 & 1.9 & 0.6 \\
& 1.2 & 1.1 & 0.9 & 1.1 & 1.2 & 0.3
\end{tabular}

Total no. of

records

55303

$61478 \quad 64234$

40242

Average no. of records in $\mathrm{HY}$ after editing 3.37 3.40 3.44 3.57 3.65 2.96

1) Year 1982 is incomplete.

2) Represents the percent of records lost in editing (see text for details).

few. The same relation can be expected to be expressed in the accuracy of sire proofs as well.

Excluding the records lost in editing, the average number of records was 5.1 in a H2Y-class and 3.5 in a HY-class (Table 2). The fraction of larger HYclasses tended to increase in the most recent years, however, and the average number of records in a HY-class in 1981 was 3.65 (Table 6).

Using parameters applicable to the Finnish dairy cattle population, a simulation study was conducted to determine the effect of the size of herdyear class on the accuracy of sire proofs. Increase of herd-year size from 2 to 3 records resulted in greatest reduction in the standard deviations of error of prediction (OJALA et al. 1983). Increase in the number of records in a HYclass above 4 or 5 records improved the accuracy of sire proofs only slightly. This is in general agreement with the study by HENDERSON (1974). It is obvious, however, that regarding the accuracy of sire proofs, the effect of the number of progeny is much more important than the size of herd-year class.

Sire proofs under the three models

The proof for a bull is $\hat{\mathrm{g}}+\hat{\mathrm{s}}$ which is the predicted difference (PD) of onehalf of a bull's additive genetic merit from the average of all sires in a run. To 
Table 7. Averages and standard deviations of predicted difference for bulls of FAy-, FFr- and Fc-breeds.

Trait and

model
Average $(\tilde{\mathrm{x}})$ and standard deviation $(\mathrm{s})$ of predicted difference ${ }^{1)}$ for the breeds of

FAy
$\mathrm{FFr}$

$\mathrm{Fc}$

Fat corrected milk, kg

Model 1:

Model 2:

Model 3:

$\begin{array}{rrrr}\overline{\mathrm{x}} & 233 & 191 & -189 \\ \mathrm{~s} & 160 & 174 & 118 \\ \mathrm{n} & 1761 & 294 & 156 \\ & & & \\ \overline{\mathrm{x}} & 250 & 206 & -180 \\ \mathrm{~s} & 159 & 168 & 117 \\ \mathrm{n} & 1761 & 294 & 156\end{array}$

$\begin{array}{rrrr}\tilde{\mathrm{x}} & 258 & 216 & -172 \\ \mathrm{~s} & 159 & 172 & 116 \\ \mathrm{n} & 1746 & 292 & 142\end{array}$

$\mathrm{n}=$ number of bulls with 20 or more progeny.

1) Predicted difference of one-half of a bull's additive genetic merit from the average of all sires in a run.

provide a stable and predetermined range and distribution, evaluations for sires are standardized within each breed to a relative scale, i.e., to be distributed normally with mean 100 and standard deviation 10. Parameters necessary to calculate a standardized evaluation, an index, were estimated from the set of sires with at least 20 daughters (Table 7).

Differences between breeds. Average PD of FCM for bulls of the FAy-, FFr- and Fc-breeds represents the average of one-half the additive genetic merit of the breeds (Table 7). Thus under model 3, the additive genetic superiority of the FAy-breed in first lactation 305-day FCM to the FFr-and Fc-breeds was 84 and $860 \mathrm{~kg}$, respectively. The genetic differences in FCM between the three breeds were slightly smaller than the corresponding differences, 104 and $873 \mathrm{~kg}$, from the raw averages for the three breeds (Appendix). The observed differences between the three breeds are under the assumption that breeds of cows, defined by the breed of sire, are as in Table 1. The fraction of crossbred cows of all cows was small, however, and was the largest for the FFr-breed. About $17 \%$ of the cows whose sire was a FFr-bull were crossbreds, the majority being of the FFr by FAy type.

Standard deviation of PD for FCM was about $160 \mathrm{~kg}$ for FAy-bulls (Table 7). This implies that the standard deviation of additive genetic values is about $320 \mathrm{~kg}$. In comparison to the FAy-breed, the corresponding variation was slightly larger in the FFr-breed, but was considerably smaller in the Fcbreed. Standard deviations of PD for FCM did not change much under any of the three models in any of the breeds.

Differences between bulls born in different years. Averages of FCM-index for the two youngest classes of FAy-bulls increased when bull groups were deleted from the model (Figure 1). Indexes for the very youngest bulls increased the most, about 3 units on the average. As a result of this change, 


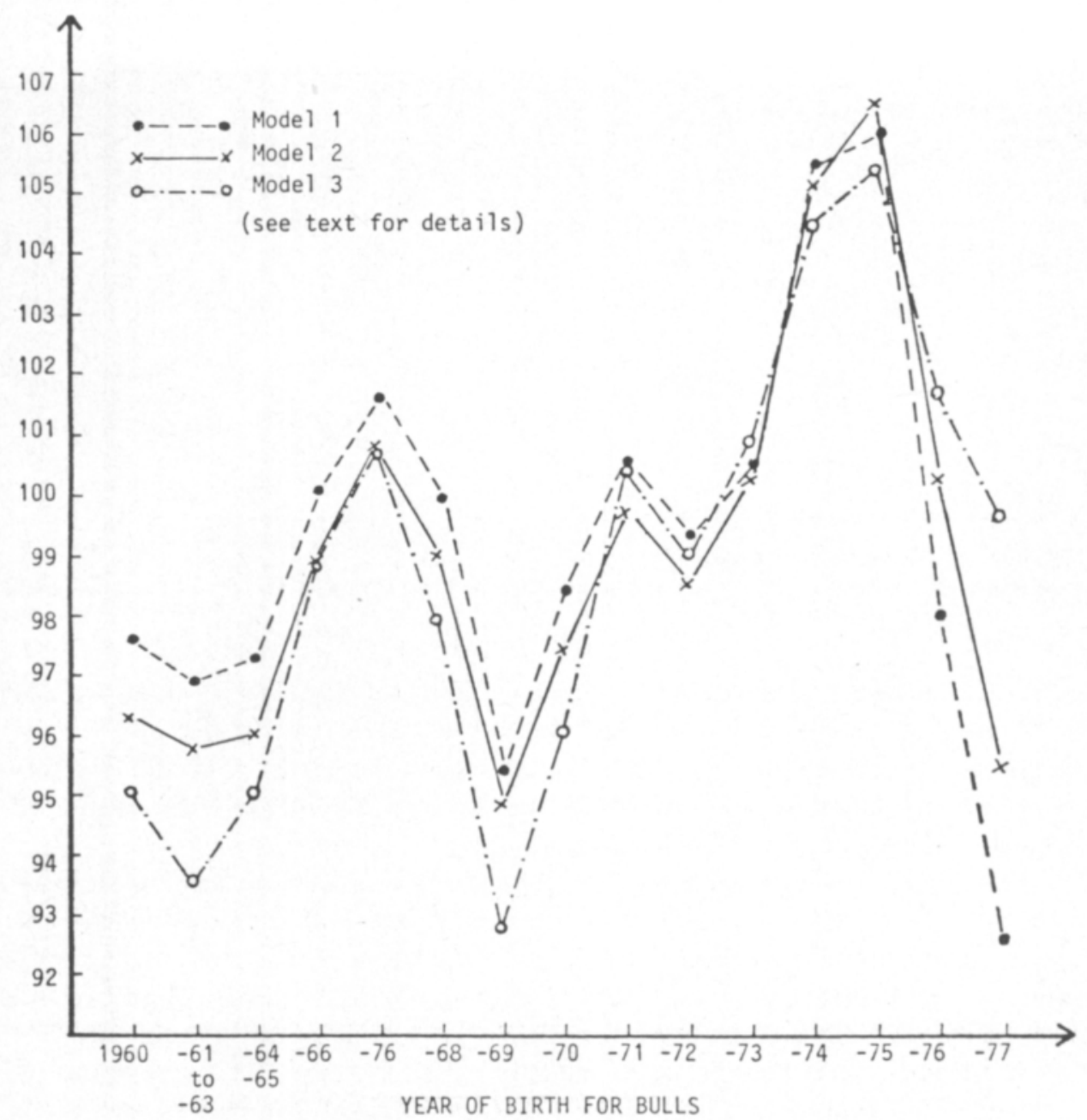

Figure 1. Average of standardized predicted difference of FCM for FAy - bulls born in different years.

the averages of FCM-index for the oldest classes of bulls decreased slightly. Thus, joint use of bull groups and relationships among males tended to underevaluate the youngest bulls and overevaluate the oldest bulls belonging to previous generations. This is an unfavorable situation with regard to sire selection, and grouping of bulls does not under the Finnish breeding structure serve the purpose originally proposed by HENDERSON (1973).

Replacing the H2Y-effect by the HY-effect in the model resulted in a similar effect in the averages of FCM-index for bulls of different ages, as mentioned in the previous paragraph. Also in this case the increase in the average index for the very youngest bulls was the largest, about 4 units (Figure 1). It should be noted, however, that the number of bulls in the youngest group was incomplete. These bulls also were those whose daugh- 
ters completed their lactations during the poor fodder year of 1981, and consequently, probably suffered the most from not having the fixed herd-year effect in the model. Even though the numbers of FFr- and Fc-bulls in a year class were relatively small (Table 2), changes in the models tended to have similar effects in all breeds.

The proposed model. Model 3 was chosen because it seemed to fit the structure of the data most appropriately. Replacing H2Y-class by HY-class in the model can be anticipated to improve the efficiency in removing the possible bias caused by year effects on sire proofs. Even though the total number of records decreased, the number of daughters for young bulls to be proved remained relatively large. Model 3 also proved to be most appropriate with regard to nominating new selected sires.

\section{Publication of sire evaluations}

Sire evaluations are published for bulls having at leat 20 daughters. The overall index was the main criterion in nominating the best bulls (Appendix). The weights needed in constructing the overall index were calculated by MÄNTYSAARI (1983) based on the principle of selection index, i.e., making use of heritabilities and economic values for the traits, and genetic correlations among the traits. The nine subindexes included in the overall index, and deviations for fat and protein percents are also listed in the sire summary.

Due to standardization, the subindexes should be within a range of 70 and 130 units in $99.74 \%$ of the cases. It is observed, however, that some very high indexes may exist (Appendix). This suggests that sire proofs for the trait in question are not normally distributed. In recent years, especially high indexes have been obtained in FCM-trait for FAy-bulls in the breeding group C. This, and the high peak in Figure 1 for bulls born in 1974 or 1975, could be partly explained by a succesful import of semen from the Norwegian bull, A. Lier. In the fall of 1983, new FAy-bulls with high FCM-index was obtained also in the breeding group D.

Acknowledgements: Dr. U. B. Lindström and Mr. Veijo Vilva, B. Sc., were also the members in the planning group for revision of sire evaluation in Finland. The computing algorithm introduced by Dr. L. R. Schaeffer during the BLUP-shop in Sweden in August 1976 was of considerable help in developing the Finnish application.

\section{References}

BOA. 1976-1983. Statistics of the activity of milk recording societies in Finland 1975-1982 (in Finnish with English summary and subtitles). Publications of Board of Agriculture No. 383, 386, 389, 393, $395,399,400$ and 403 .

CAAIS. 1983. Artificial insemination in Finland 1982. 35 p. Central Association of A.I. Societies, PB 25, 01301 Vantaa 30, Finland. 
CHRISTENSEN, L. G. 1980. Direct updating as a method for estimating breeding values in cattle (in Danish with English survey and subtitles). Beretning fra Statens Husdyrbrugs forsög No. 489, 270 p.

CUNNINGHAM, E. P. 1983. Structure of dairy cattle breeding in Western Europe and comparisons with North America. J. Dairy Sci. 66: 1579-1587.

DANELL, B. \& ERIKSSON, J.-A. 1982. The direct sire comparison method for ranking of sires for milk production in the Swedish dairy cattle population. Acta Agric. Scand. 32: 47-64.

DEMPFLE, L. 1982. Problems in estimation of breeding values. 2nd World Congress on Genetics Applied to Livestock Production. Madrid. Vol. 5: 104-118.

EVERETT, R. W., QUAAS, R. L. \& McCLINTOKC, A. E. 1979. Daughters' maternal grandsires in sire evaluation. J. Dairy Sci. 62: 1304-1313.

FAMULA, T. R. \& VAN VLECK, L. D. 1982. Monte Carlo study of genetic groups in sire evaluation. J. Dairy Sci. 65: 1286-1293.

-, POLLAK, E. J. \& VAN VLECK, L. D. 1983. Genetic groups in dairy sire evaluation under a selection model. J. Dairy Sci. 66: 927-934.

FIMLAND, E. A. 1976. Estimation of sire's breeding value. VI. Different linear prediction methods discussed in the context of the breeding structure of the population. Z. Tierzüchtg. Züchtungsbiol. 93: $14-30$.

HEIDHUES, T., VAN VLECK, L. D. \& HENDERSON, C. R. 1961. Actual and expected accuracy of sire proofs under the New York system of sampling bulls. Z. Tierzüchtg. Züchtungsbiol. 75 : 323330.

HENDERSON, C. R. 1973. Sire evaluation and genetic trends. Proc. of the Anim. Breed. and Genet. Symp. in Honor of Dr. Jay L. Lush. July 29, 1972, Blacksburg, Va. pp: 10-41.

,- 1974 . Effect of herd size on accuracy of comparison method of sire evaluation. J. Anim. Sci. 57:613 (Abstr.).

- 1975. Inverse of a matrix of relationships due to sires and maternal grandsires. J. Dairy Sci. 58: 1917-1921.

JENSEN, E. L. 1980. Bull groups and relationships among sires in Best Linear Unbiased Prediction sire evaluation models. J. Dairy Sci. 63: 2111-2120.

KENNEDY, B. W. 1981. Bias and mean square error from ignoring genetic groups in mixed model sire evaluation. J. Dairy Sci. 64: 689-697.

- \& MOXLEY, J. E. 1975. Comparison of genetic group and relationship methods for mixed model sire evaluation. J. Dairy Sci. 58: 1507-1514.

LINDSTRÖM, U., MAIJALA, K. \& VARO, M. 1973. Dairy progeny testing in Finland. J. Scient. Agric. Soc. Finland 45: 565-571.

MÄNTYSAARI, E. 1983. A multitrait selection index for dairy bulls (in Finnish). Unpublished M. Sc. Thesis. Univ. of Helsinki, Dept. of. Anim. Breed.

OJALA, M., SYVÄJÄRVI, J. \& HELLMAN, T. 1983. Effect of herd size on the accuracy of sire proofs. Unpublished, work in progress.

POLLAK, E. J. \& QUAAS, R. L. 1983. Definition of group effects in sire evaluation models. J. Dairy Sci. 66: $1503-1509$.

QUAAS, R. L. \& POLLAK, E. J. 1981. Modified equations for sire models with groups. J. Dairy Sci. 64: $1868-1872$.

SWALVE, H. \& BRUNS, E. 1983. Use of relationship matrices in BLUP dairy sire evaluation procedures. 34th Ann. Meet. of EAAP, Madrid. Mimeogr. 14 p.

THOMPSON, R. 1979. Sire evaluation. Biometrics 35: 339-353.

VARO, M. 1952. Untersuchungen über die Steigerungs-möglichkeiten der Viehzüchtung unter besonderer Berücksichtigung der Bullenauslese (in Finnish with German survey and subtitles), Acta Agr. Fenn. 77, 156 p.

- 1958. Über die Brauchbarkeit unserer Bullenwerte auf den Verschiedenen Leistungsstufen. Acta Agr. Fenn. 93, 4: 1-31.

Ms received December 8, 1983 


\title{
Suoran vertailumenetelmän soveltaminen sonnien jälkeläisarvoste- luun Suomessa
}

\author{
Jouko Syväjärvi ${ }^{1}$, Matti Ojala ${ }^{2}$ ja Tapani Hellman ${ }^{3}$ \\ ${ }^{1}$ Suomen Kotieläinjalostusyhdistys, nautakarjaosasto \\ ${ }^{2}$ Helsingin Yliopisto, kotieläinten jalostustieteen laitos \\ ${ }^{3}$ Keinosiemennysyhdistysten Liitto, Maatalouden Laskentakeskus
}

Vuonna 1981 aikaisemmin käytetty sonnien jälkeläisarvostelumenetelmä korvattiin uudella lineaarisen, kiinteitä ja satunnaistekijöitä sisältävän mallin (BLUP $=$ Best Linear Unbiased Prediction) hyväksikäyttöön perustuvalla ns. suoran vertailun menetelmällä. Käyttöön otettu menetelmä sellaisenaan on yksiselitteinen, mutta myös laskentamallin on oltava hyvin todellista tilannetta kuvaava, ennen kuin voidaan laskea varmat ja harhattomat arvostelut.

Tässä tutkimuksessa verrattiin keskenään kolmea vaihtoehtoista mallia pyrkien siten arvioimaan toisaalta karja-vuositekijän muodostamistavan ja toisaalta sonnien ryhmittelymenettelyn vaikutusta arvostelutuloksiin.

Tutkimusaineisto käsitti 400542 ensikon tuotostiedot vuosilta 1975-82. Ensikoiden 305 päivän tuotokset oli ennen tulosten laskentaa korjattu ikä-poikimakuukauden ja tyhjäkauden vaikutusten eliminoimiseksi. Ensikoista $83 \%$ oli ayrshirerotua, $13 \%$ friisiläisiä, $2 \%$ suomenkarjaa ja $2 \% \mathrm{em}$. rotujen risteytyksiä.

Varianssianalyysi osoitti karjojen väliseksi vaihteluosuudeksi $37 \%$ ensikoiden neliprosenttiseksi muunnetun 305 päivän maitotuotoksen vaihtelusta. Vuosien välinen vaihtelu karjojen sisällä oli $7 \%$ kokonaisvaihtelusta. Vastaavat osuudet valkuaistuotoksen vaihtelusta olivat 42 $\%$ ja $9 \%$.

Jälkeläisarvostelun laskentamallissa (BLUP-mallissa) oletetaan karja-vuositekijä kiinteäksi. Kun ensikoita verrataan keskenään karja-vuosiluokissa, vertailua ei voida tehdä, jos luokassa on vain yksi havainto. Tällaiset tuotostiedot joudutaan hylkäämään. Kun karja-vuositekijä muodostettiin kahden vuoden jaksoissa, tuotoksista jouduttiin hylkäämään $4 \%$. Kun jaksot muodostettiin vuosittain, hylkäysprosentti oli 11. Karjojen keskilehmäluku ja samalla karjojen ensikoiden keskimääräinen luku on vuosittain kasvanut. Vuonna 1981 enää vain $7 \%$ ensikoista oli sellaisissa karjoissa, joissa ei samanaikaisesti ollut toista ensikkoa.

Vähintään 20 tyttären tuotostietojen perusteella arvosteltujen sonnien tytärluku väheni keskimäärin $9 \%$, kun kaksivuotisen karja-vuosijakson sijasta käytettiin yksivuotista jaksoa.

Tutkimus osoitti, että sonnien tyttärien lukumäärä on tärkein arvostelun varmuuteen vaikuttava tekijä ja ettei arvostelun varmuus oleellisesti heikkene, vaikka kaksivuotisen karjavuosijaksotuksen sijasta käytettäisiin yksivuotista jaksotusta. Yksivuotisella jaksotuksella voidaan kaksivuotista jaksotusta paremmin ehkäistä $\mathrm{mm}$. erilaisten rehuvuosien vaikutus arvostelutuloksiin.

Maitotuotosten vuotuinen vaihtelu johtuu sekä ympäristöstä että eri vuosina arvosteltujen sonnien perinnöllisen tason vaihtelusta. Siksi jokainen sonnivuosiluokan keskiarvo ei ole korkekampi kuin edellisen vuoden keskiarvo, eikä kaikkina vuosina voida odottaa saatavan uusia huippusonneja.

Käyttämällä mallissa sonnien geneettisen ryhmän perusteella muodostettua tekijää pyritään eliminoimaan valinnan aiheuttamien geneettisten tasoerojen vaikutus arvostelutuloksiin. Tutkimus osoitti, että jos geneettiset ryhmät muodostetaan sonnien iän perusteella ja samanaikaisesti otetaan huomioon sonnien keskinäiset sukulaisuudet, nuoret sonnit joutuvat aliarvostetuiksi suhteessa vanhoihin sonneihin. Kun sonnit jaettiin geneettisiin ryhmiin vain rodun mukaan, nuorimpien sonnien arvostelutulosten keskiarvo kohosi 4 indeksipistettä verrattuna tilanteeseen, jossa sonnit ryhmiteltiin sekä iän että rodun perusteella.

Käyttökelpoisimmaksi osoittautui malli, jossa karja-vuosiluokat noudostetaan vuoden jaksoissa ja geneettiset ryhmät yksinomaan rodun perusteella. 


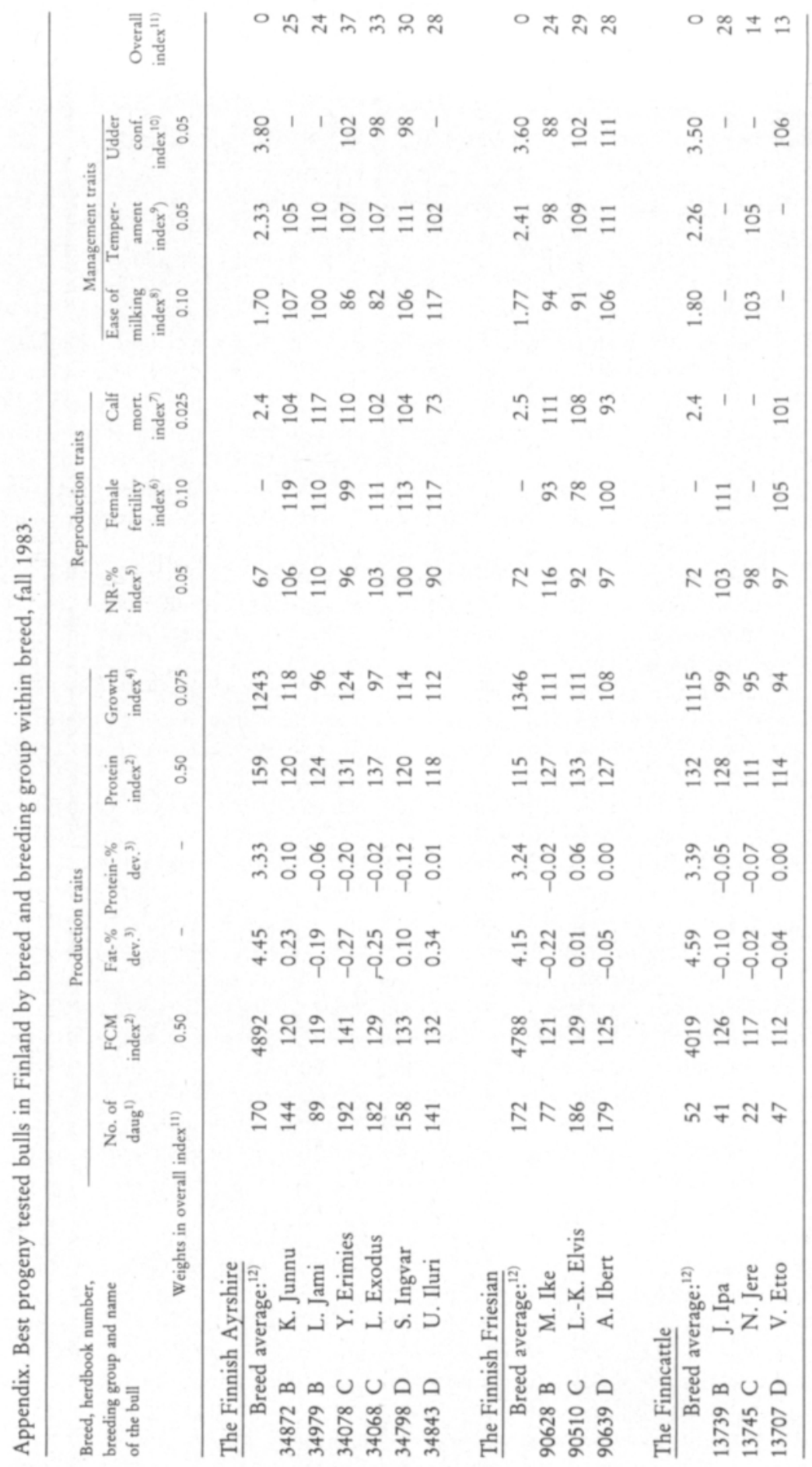




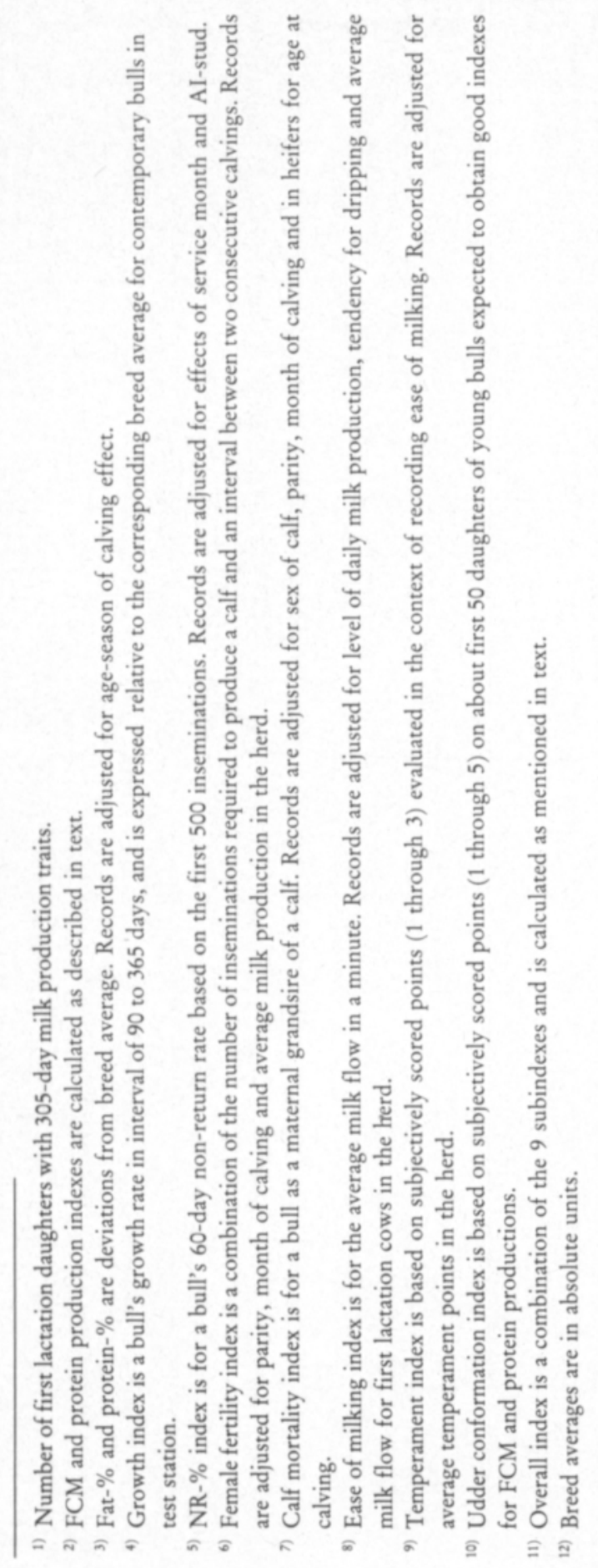

